This document was prepared in conjunction with work accomplished under Contract No. DE-AC09-96SR18500 with the U. S. Department of Energy.

\title{
DISCLAIMER
}

This report was prepared as an account of work sponsored by an agency of the United States Government. Neither the United States Government nor any agency thereof, nor any of their employees, nor any of their contractors, subcontractors or their employees, makes any warranty, express or implied, or assumes any legal liability or responsibility for the accuracy, completeness, or any third party's use or the results of such use of any information, apparatus, product, or process disclosed, or represents that its use would not infringe privately owned rights. Reference herein to any specific commercial product, process, or service by trade name, trademark, manufacturer, or otherwise, does not necessarily constitute or imply its endorsement, recommendation, or favoring by the United States Government or any agency thereof or its contractors or subcontractors. The views and opinions of authors expressed herein do not necessarily state or reflect those of the United States Government or any agency thereof. 
WSRC-TR-2005-00573

\section{SELECT THERMAL AND PHYSICAL PROPERTY DATA FOR LEAD CARBONATE (U)}

\section{W. L. Daugherty}

Savannah River National Laboratory

Materials Science \& Technology

Publication Date: December 2005

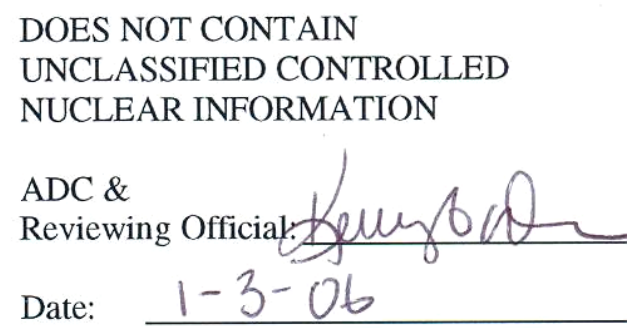

\section{Westinghouse Savannah River Company}

Savannah River Site

Aiken, SC 29808

This document was prepared in connection with work done under Contract No. DEAC09-96SR18500 with the U. S. Department of Energy 
WSRC-TR-2005-00573

\section{DISCLAIMER}

This report was prepared for the United States Department of Energy under Contract No. DE-AC09-96SR18500 and is an account of work performed under that contract. Neither the United States Department of Energy, nor WSRC, nor any of their employees makes any warranty, expressed or implied, or assumes any legal liability or responsibility for accuracy, completeness, or usefulness, of any information, apparatus, or product or process disclosed herein or represents that its use will not infringe privately owned rights. Reference herein to any specific commercial product, process, or service by trade name, trademark, name, manufacturer or otherwise does not necessarily constitute or imply endorsement, recommendation, or favoring of same by Westinghouse Savannah River Company or by the United States Government or any agency thereof. The views and opinions of the authors expressed herein do not necessarily state or reflect those of the United States Government or any agency thereof. 
WSRC-TR-2005-00573

\section{Select Thermal and Physical Property Data for Lead Carbonate (U)}

APPROVALS:

W. L. Daugherty

Author

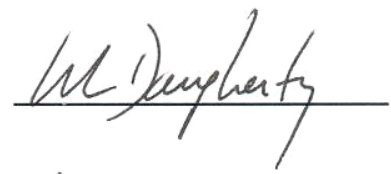

Date $29 \mathrm{Dec} 2005$

K. A. Dunn

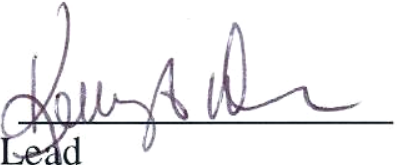

Date Jan. 3, 2006 SRNL Pu Surveillance Program Lead

N. C. Iyer

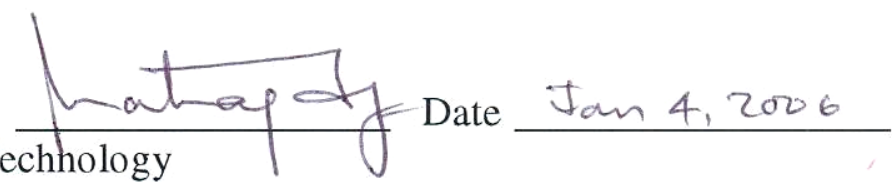

B. M. Loftin

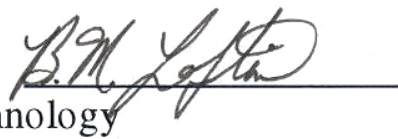

Date Jamuary 3,2006 Savannah River Packaging Technology

K. H. Subramanian Wurttuth hlin Date January 9/2006 Technical Review 
WSRC-TR-2005-00573

\section{Revision Log}

$\begin{array}{lll}\text { Document No. WSRC-TR-2005-00573 Rev. No. } 0 & \text { R }\end{array}$

Document Title Select Thermal and Physical Property Data for Lead Carbonate (U)

Rev. \# Page \# Description of Revision Date

0 all Original document 12/29/2005 


\section{Select Thermal and Physical Property Data for Lead Carbonate (U)}

\section{Introduction}

The 9975 shipping package has been used for shipping and storing radioactive materials. Field surveillance activities of 9975 shipping packages following storage in the K Area Material Storage (KAMS) facility have identified that a lead carbonate layer forms on the shield of these packages after a period of time. Analysis of this corrosion product has identified the presence of lead carbonate $\left(\mathrm{PbCO}_{3}\right)$ and/or basic lead carbonate $\left(2 \mathrm{PbCO}_{3}\right.$ $\left.\mathrm{Pb}(\mathrm{OH})_{2}\right)$. In order to update calculations of the performance of the package in service, Materials Science \& Technology was requested to compile thermal and physical properties of lead carbonate. This report transmits the information which was located.

The requested properties include thermal conductivity, specific heat capacity, density and emissivity. Several of the identified properties were found in the literature, and others were not. For the properties that were not located for lead carbonate, the same properties were located for other compounds which might behave similar to lead carbonate. Some general guidance as to the applicability of these data to lead carbonate is provided in lieu of actual lead carbonate properties. Where data were provided for both lead carbonate and basic lead carbonate, the values for each are reported. However, in most cases basic lead carbonate was not included in the references.

\section{Data}

Several references were located which contain the identified properties for lead carbonate in particular, or for a number of compounds in general. Thermal conductivity data for lead carbonate was not found in any of the listed references. In this case, thermal conductivity data for a variety of other compounds is identified, and used to provide a potential range for lead carbonate. While specific heat capacity data for lead carbonate was identified, a comparison to other compounds was made prior to locating that data. This comparison is included for completeness. Data for density and emissivity of lead carbonate were located, and are reported. Should additional information be required, further searches might focus on information from the paint/pigment industry.

\section{Thermal Conductivity}

Thermal conductivity data for lead carbonate was not found. However, Reference 1 compiles thermal conductivity data for a number of other compounds. Data for several compounds which might be similar to lead carbonate are listed in Table 1. 
Table 1. Thermal conductivity for compounds which might behave similar to lead carbonate. Data are for 300K unless otherwise noted.

\begin{tabular}{|c|c|}
\hline Compound & Thermal Conductivity (w/cm-K) \\
\hline $\mathrm{MgCO}_{3}$ & 0.0465 \\
\hline $\mathrm{CaCO}_{3}$ (marble powder) & $0.005-0.006$ \\
\hline $\mathrm{PbO}+\mathrm{SiO} 2$ & 0.0053 \\
\hline $\mathrm{SiO}_{2}$ crystalline & $0.06-0.12$ \\
\hline $\mathrm{SiO}_{2}$ fused & $0.01-0.02$ \\
\hline $\mathrm{PbTiO}_{3}$ & $\sim 0.04, \sim 0.03(\sim 580 \mathrm{~K})$ \\
\hline $\mathrm{PbZrO}_{3}$ & $0.0136(345 \mathrm{~K}), 0.0150(530 \mathrm{~K})$ \\
\hline $\mathrm{KNO}_{3}$ & $0.0090(353 \mathrm{~K}), 0.0045(573 \mathrm{~K})$ \\
\hline $\mathrm{AgNO}_{3}$ & $0.00447(469 \mathrm{~K})$ \\
\hline $\mathrm{NaNO}_{3}$ & $0.00565(582 \mathrm{~K})$ \\
\hline
\end{tabular}

The following observations are drawn from the thermal conductivity data.

- Two other carbonate compounds have values ranging from 0.005 to $0.046 \mathrm{w} / \mathrm{cm}-\mathrm{K}$.

- Three nitrate compounds have values from 0.004 to $0.009 \mathrm{w} / \mathrm{cm}-\mathrm{K}$

- The range among the three nitrate compounds is relatively small, and similar to the value for $\mathrm{CaCO}_{3}$.

- Since the values for $\mathrm{SiO}_{2}$ are much higher than those for $\mathrm{PbO}+\mathrm{SiO}_{2}$, the value for just $\mathrm{PbO}$ may be less than $0.005 \mathrm{w} / \mathrm{cm}-\mathrm{K}$

- Values for 2 other oxides are 0.014 and $0.04 \mathrm{w} / \mathrm{cm}-\mathrm{K}$

- Over the temperature ranges given in the reference (not included in Table 1), values for the carbonates vary more with temperature (data for $\sim 300 \mathrm{~K}$ and lesss) than values for the lead oxides.

There are no obvious trends among these compounds that suggest a likely thermal conductivity value for $\mathrm{PbCO}_{3}$. It may be that the primary factor influencing thermal conductivity is the form of the material; a porous layer of any of these compounds will be a relatively effective thermal insulator. Reference 1 in turn lists the sources from which this data was compiled. It may be possible to track down these source references and determine which compounds were tested in a form most like the $\mathrm{PbCO}_{3}$ film that forms on a 9975 lead shield. Otherwise, the limiting value listed above (0.004 or 0.046 $\mathrm{w} / \mathrm{cm}-\mathrm{K}$, each value might be limiting for different scenarios) might be an appropriate approximation.

Specific Heat Capacity Specific heat capacity data for lead carbonate were found in Reference 2, and are summarized in Table 2. 
Table 2. Specific heat capacity for lead carbonate. Data from Reference 2 are in cal $/ \mathrm{mol}-$ $\mathrm{K}$. These values are also shown converted to cal/g-K.

\begin{tabular}{|l|l|l|l|l|}
\hline $\mathrm{T}(\mathrm{K})$ & $\begin{array}{l}\mathrm{PbCO}_{3} \mathrm{cal} / \mathrm{mol}- \\
\mathrm{K}\end{array}$ & $\mathrm{PbCO}_{3} \mathrm{cal} / \mathrm{g}-\mathrm{K}$ & $\begin{array}{l}\mathrm{PbO}-\mathrm{PbCO}_{3} \\
\mathrm{cal} / \mathrm{mol}-\mathrm{K}\end{array}$ & $\begin{array}{l}\mathrm{PbO}-\mathrm{PbCO}_{3} \\
\mathrm{cal} / \mathrm{g}-\mathrm{K}\end{array}$ \\
\hline 298 & 20.917 & 0.0783 & 31.875 & 0.0650 \\
\hline 300 & 20.970 & 0.0785 & 31.940 & 0.0651 \\
\hline 400 & 23.830 & 0.0892 & 35.440 & 0.0723 \\
\hline 500 & 26.690 & 0.0999 & 38.940 & 0.0794 \\
\hline 600 & 29.550 & 0.111 & 42.440 & 0.0865 \\
\hline 700 & 32.410 & 0.121 & 45.940 & 0.0937 \\
\hline 800 & 35.270 & 0.132 & & \\
\hline
\end{tabular}

Conversion from mol to g: $267.1 \mathrm{~g} / \mathrm{mol} \mathrm{PbCO}_{3}, 490.41 \mathrm{~g} / \mathrm{mol} \mathrm{PbO}-\mathrm{PbCO}_{3}$

It is possible that the carbonate layer might form along with an oxide layer, or on top of an oxide layer. If this is considered credible, the data for $\mathrm{PbO}-\mathrm{PbCO}_{3}$ might be considered. Otherwise the $\mathrm{PbCO}_{3}$ data would be appropriate.

Prior to locating the above data, the specific heat capacity data for similar compounds were examined. These data are in Table 3. It is noted that the specific heat capacity generally varies with the molecular weight. A consistent trend was observed between the weight of the metal atom and the specific heat capacity of the carbonate compound for those compounds with a single metal atom. The data for these compounds at $300 \mathrm{~K}$ are plotted in Figure 1. A curve fit for these data identified by Excel spreadsheet is extrapolated to the atomic weight of lead. It is noted from Figure 1 that this gives very close agreement to the value reported in Reference 2. This relationship is shown primarily to suggest possible approaches in the use of the thermal conductivity data above.

Table 3. Specific heat capacity $(\mathrm{Cp})$ for several carbonate compounds. Units are cal/g-K

\begin{tabular}{|l|l|l|l|l|}
\hline Compound & At. Wt. of metal & Cp at $100 \mathrm{~K}$ & $\mathrm{Cp}$ at 300K & $\mathrm{Cp}$ at $600 \mathrm{~K}$ \\
\hline $\mathrm{PbCO}_{3}$ & 207.2 & & & \\
\hline $\mathrm{BaCO}_{3}$ & 137.3 & 0.0608 & 0.104 & 0.1368 \\
\hline $\mathrm{Ag}_{2} \mathrm{CO}_{3}$ & 107.9 & 0.0614 & 0.097 & \\
\hline $\mathrm{SrCO}_{3}$ & 87.6 & $\sim 0.07$ & $\sim 0.13$ & \\
\hline $\mathrm{MnCO}_{3}$ & 54.9 & & $\sim 0.17$ & $\sim 0.22$ \\
\hline $\mathrm{CaCO}_{3}$ & 40.1 & $\sim 0.09$ & 0.2 & $\sim 0.19$ \\
\hline $\mathrm{Li}_{2} \mathrm{CO}_{3}$ & 6.9 & & & 0.5 \\
\hline
\end{tabular}




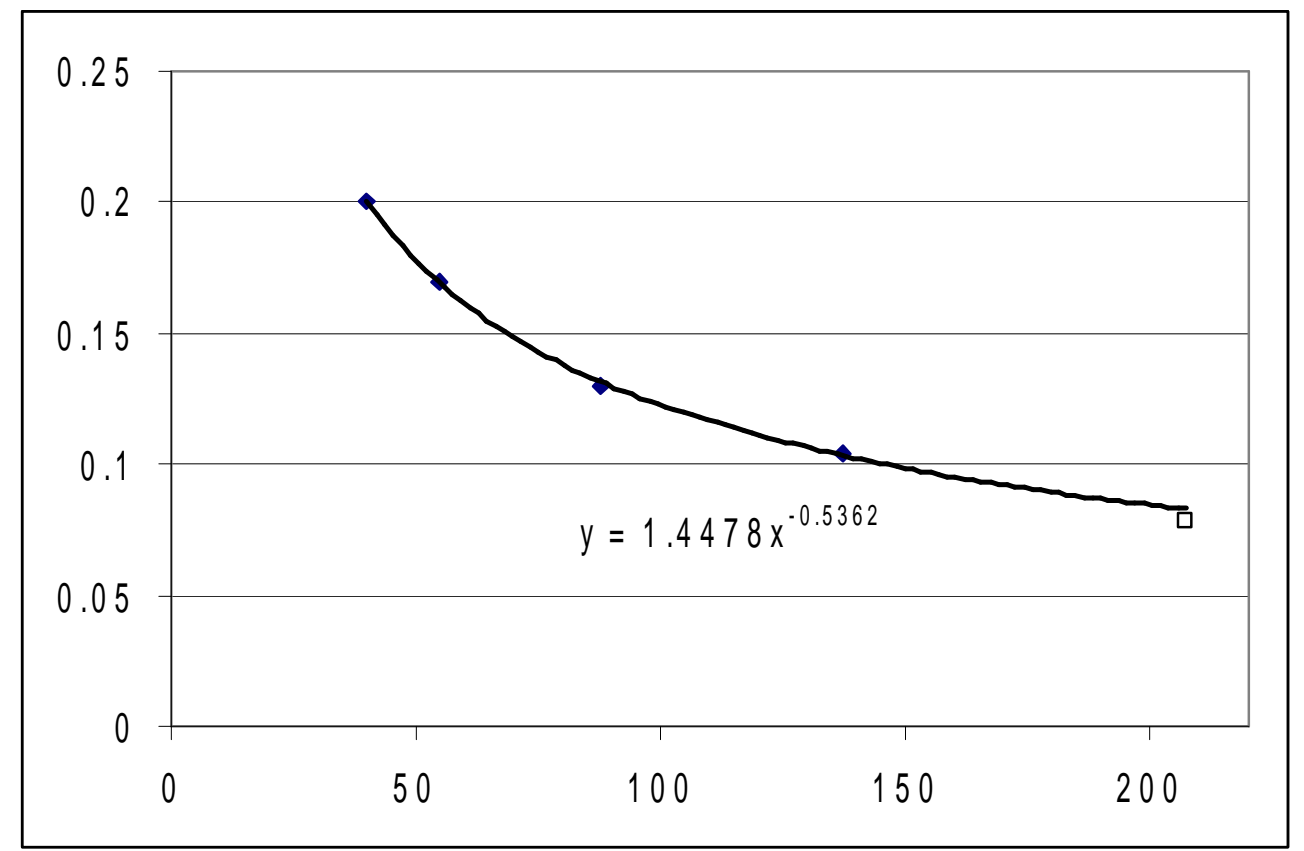

Figure 1. Specific heat capacity of carbonate vs atomic weight of metal (for compounds with a single metal atom). Curve fit by Excel spreadsheet is extrapolated to the atomic weight of lead.

Density

The following data are found in both References 4 and 5.

Lead carbonate, $\mathrm{PbCO}_{3}, 6.6$ specific gravity

Basic lead carbonate, $2 \mathrm{PbCO}_{3} \mathrm{~Pb}(\mathrm{OH})_{2}, 6.14$ specific gravity

In contrast, Reference 6 identifies a slightly different value for basic lead carbonate. It gives the following data:

Lead carbonate, $\mathrm{PbCO}_{3}, 6.6 \mathrm{~g} / \mathrm{cc}$ density

Basic lead carbonate, $2 \mathrm{PbCO}_{3} \mathrm{~Pb}(\mathrm{OH})_{2}, \sim 6.5 \mathrm{~g} / \mathrm{cc}$ density

\section{Emissivity}

Reference 7 identifies the following data for lead carbonate emissivity.

Table 4. Lead carbonate emissivity

\begin{tabular}{|l|l|}
\hline Temperature $(\mathrm{C})$ & Emissivity $(\%)$ \\
\hline 52 & 89 \\
\hline 400 & 71 \\
\hline 2750 & 8 \\
\hline solar & 12 \\
\hline
\end{tabular}

Reference 5 provides the following emissivity data.

For oxidized $\mathrm{Pb}$ (metal, not carbonate), emissivity (total) $=0.05$ at $200 \mathrm{C}$

For unoxidized $\mathrm{Pb}$ (metal, not carbonate), emissivity (total) $=0.63$ at 200C 
Two additional references for emissivity data were cited, but the references $(8,9)$ were not located for this review.

\section{Summary}

Specific heat capacity, density and emissivity data for lead carbonate were identified and reported. The density of basic lead carbonate was also reported. The thermal conductivity of lead carbonate was not found, but the thermal conductivity of a number of other compounds is summarized. A correlation was observed between the metal atomic weight and specific heat capacity for several carbonate compounds. While this specific relationship does not appear applicable to the thermal conductivity, it might suggest an alternate approach to estimate the thermal conductivity of lead carbonate. However, in the absence of any demonstrated relationship, it is recommended that the maximum or minimum value reported for other compounds (whichever is more limiting) be used for lead carbonate.

\section{References}

1. Thermophysical Properties of Matter, Vol. 2, Thermal Conductivity Nonmetallic Solids, Y. S. Touloukian, R. W. Powell, C. Y. Ho and P. G. Klemens, IFI/Plenum, 1970

2. Thermochemical Properties of Inorganic Substances, I. Barin and O. Knacke, Springer-Verlag, 1973

3. Thermophysical Properties of Matter, Vol. 5, Specific Heat Nonmetallic

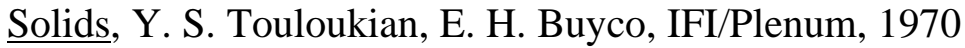

4. $\quad$ Lead in Modern Industry, Lead Industries Association, 1952

5. $\quad$ CRC Handbook of Chemistry and Physics, $66^{\text {th }}$ Ed, CRC Press, 1985

6. $\quad$ CRC Handbook of Chemistry and Physics, $79^{\text {th }}$ Ed, CRC Press, 1998

7. Gmelins Handbuch der Anorganischen Chemie, Blei, Teil C, Lieferung 2, G. Hantke, Verlag Chemie, 1969, p. 47

8. "Some Optical Properties of White Paint Pigments in the Ultra-Violet Spectrum", Pfund A H, Am Soc Testing Materials Proc, 23, 369-78, 1923

9. "Reflection Factors of Industrial Paints and Pigments", Gardner Henry A, Trans Illum Eng Soc / N Y /, 17, 318-22, 1922 
WSRC-TR-2005-00573

cc: $\quad$ B. M. Loftin, 773-41A

T. K. Houghtaling, 773-41A

J. S. Bellamy, 773-41A

K. A. Dunn, 773-41A

G. T. Chandler, SRNL

K. H. Subramanian, SRNL

J. L. Murphy, 730-4B

K. J. Durrwachter, 705-K

E. L. Bryant, 705-K

S. T. Sweat, 773-52A Document Control 